\title{
The Relation of Exocytosis and Rapid Endocytosis to Calcium Entry Evoked by Short Repetitive Depolarizing Pulses in Rat Melanotropic Cells
}

\author{
Huibert D. Mansvelder and Karel S. Kits \\ Research Institute Neurosciences Vrije Universiteit, Faculty of Biology, Membrane Physiology Section, 1081 HV, \\ Amsterdam, The Netherlands
}

\begin{abstract}
Melanotropic cells release predocked, large, dense-cored vesicles containing $\alpha$-melanocyte stimulating hormone in response to calcium entry through voltage-gated calcium channels. Our first objective was to study the relationship between exocytosis, rapid endocytosis, and calcium entry evoked by short step depolarizations in the order of duration of single action potentials (APs). Exocytosis and rapid endocytosis were monitored by capacitance measurements. We show that short step depolarizations (40 msec) evoke the fast release of only $\sim 3 \%$ of the predocked release-ready vesicle pool. Second, we asked what the distance is between voltage-gated calcium channels and predocked vesicles in these cells by modulating the intracellular buffer capacity. Exocytosis and rapid endocytosis were differentially affected by low concentrations of the calcium chelator EGTA. EGTA slightly attenuated exocytosis at $100 \mu \mathrm{m}$ relative to $50 \mu \mathrm{M}$, but exocytosis was strongly depressed at $400 \mu \mathrm{M}$, showing that calcium ions have to travel a large distance to
\end{abstract}

stimulate exocytosis. Nevertheless, the efficacy of calcium ions to stimulate exocytosis was constant for pulse durations between 2 and $40 \mathrm{msec}$, indicating that in melanotropes, exocytosis is related linearly to the amount and duration of calcium entry during a single AP. Rapid endocytosis was already strongly depressed at $100 \mu \mathrm{M}$ EGTA, which shows that the process of endocytosis itself is calcium dependent in melanotropic cells. Furthermore, rapid endocytosis proceeded with a time constant of $\sim 116 \mathrm{msec}$ at $33^{\circ} \mathrm{C}$, which is three times faster than at room temperature. There was a strong correlation between the amplitude of endocytosis and the amplitude of exocytosis immediately preceding endocytosis. Both this correlation and the fast time constant of endocytosis suggest that the exocytotic vesicle is retrieved rapidly.

Key words: exocytosis; endocytosis; calcium entry; channels; EGTA; BAPTA; pituitary; $\alpha M S H$
Neurons and neuroendocrine cells can release exocytotic vesicles within milliseconds (Augustine et al., 1985; Thomas et al., 1993a,b; Heinemann et al., 1994; Borst and Sakmann, 1996; Mennerick and Matthews, 1996). In both cell types, vesicles lie predocked to the plasma membrane awaiting the trigger for release. In melanotropic cells, of the $\sim 3300$ vesicles that are morphologically found to be predocked to the plasma membrane, only $\sim 250$ are readily releasable within $40 \mathrm{msec}$ on an immediate uniform rise in $\left[\mathrm{Ca}^{2+}\right]_{\mathrm{i}}$ (Thomas et al., 1993a,b; Parsons et al., 1995). The remaining $90 \%$ need additional priming steps, giving rise to slower components of exocytosis.

In synapses, the predocked release-ready vesicles are molecularly linked to calcium channels (Calakos and Scheller, 1996). Release of these vesicles occurs immediately on calcium channel opening (Mennerick and Matthews, 1996), thereby warranting a strong synchronization between action potential (AP) and secretion of transmitter. In isolated chromaffin cells, the timing of release is not strictly coupled to calcium current kinetics, and single APs only infrequently trigger release (Zhou and Misler, 1995). When longer step depolarizations are used, exocytosis

Received June 10, 1997; revised Oct. 13, 1997; accepted Oct. 15, 1997.

This work was supported by an NWO-Medical Research Council Grant (900-553035). We thank Jacqueline Leyting-Vermeulen for preparing the cell culture and Paul van Soest for help with programming. We thank Drs. Arjen Brussaard, Paul van Soest, Hind van Tol, and Theo de Vlieger for comments on this manuscript.

Correspondence should be addressed to Karel S. Kits, Research Institute Neurosciences Vrije Universiteit, Faculty of Biology, Membrane Physiology Section, De Boelelaan 1087, $1081 \mathrm{HV}$, Amsterdam, The Netherlands.

Copyright (C) 1997 Society for Neuroscience $0270-6474 / 97 / 180081-12 \$ 05.00 / 0$ persists after calcium entry has stopped (Chow et al., 1992). This time delay of release is thought to arise from the separation of calcium channel and docking site, thus necessitating diffusion of calcium between channel and release site (Chow et al., 1996).

Most data on exocytosis in the melanotropic cells from the intermediate pituitary were obtained using flash photolysis of caged calcium, generating high sustained calcium levels (Thomas et al., 1990; 1993a,b; Parsons et al., 1995). Melanotropic cells generate both sodium and calcium spikes (Douglas and Taraskevich, 1980; Williams et al., 1990). These phenomena range in duration from a few milliseconds for sodium spikes to tens of milliseconds for the calcium spikes. The intracellular calcium profiles thus produced differ strongly from the long uniform increases by flash photolysis of caged calcium or the increases produced by long step depolarizations. Here we examine the coupling between release and short depolarizations in melanotropic cells. Specifically, we wanted to know whether the predocked release-ready vesicles are located near calcium channels or whether calcium has to diffuse a substantial distance to the release site.

Membrane capacitance measurements were used to monitor changes in cell surface area (Neher and Marty, 1982). We found that in response to a $40 \mathrm{msec}$ step depolarization only a small portion $(\sim 3 \%)$ of the release-ready vesicles is released. Moreover, this rapid release was depressed at low micromolar concentrations of intracellular EGTA $(\geq 400 \mu \mathrm{M})$, indicating that the distance separating vesicles from calcium channels is large in comparison with synapses. Rapid endocytosis was observed only at low buffering conditions (50 $\mu \mathrm{M}$ EGTA) and was strongly coupled to 
exocytosis. Despite this large distance between calcium channel and predocked vesicle, melanotropic cells on average release one vesicle per $2 \mathrm{msec}$ depolarization. In addition, exocytosis was linearly related to the amount and duration of calcium entry, suggesting that in melanotropic cells the amount of release can be regulated by the duration of an AP.

A preliminary account of some of this work has been published previously (Mansvelder and Kits, 1997).

\section{MATERIALS AND METHODS}

Cell culture. Pituitary melanotropic cells of male Wistar rats (200-300 gm; Harlan CPB, Zeist, Netherlands) were isolated as described previously (Keja et al., 1991). The cells were cultured on poly-L-lysine-coated coverslips $(7 \times 7 \mathrm{~mm})$ at a density of 0.25 intermediate lobe per coverslip. The culture medium consisted of Biorich I (Flow), $\mathrm{NaHCO}_{3} 26.2 \mathrm{~mm}$, Ultroser G 5\% (Life Technologies, Gaithersburg, MD), penicillin G $200 \mathrm{U} / \mathrm{ml}$ (Sigma, St. Louis, MO), streptomycin $50 \mu \mathrm{g} / \mathrm{ml}$ (Sigma), and cytosine arabinosine $1 \mu \mathrm{M}$ (Sigma) adjusted to $\mathrm{pH} 7.2$ with $\mathrm{NaOH}$. Cells were maintained in a $37^{\circ} \mathrm{C}$ incubator with a humidified atmosphere comprising $5 \% \mathrm{CO}_{2}$ in air. Recordings were made up to $4 \mathrm{~d}$ after isolation.

Recording solutions. Coverslips bearing melanotropic cells were transferred to the recording chamber containing $\sim 0.5 \mathrm{ml}$ external solution. The external solution consisted of (in mM): TEACl 142; glucose 10; $\mathrm{CaCl}_{2}$ 5; HEPES 10; 4-aminopyridine 1; pH adjusted to 7.4 with TEAOH. The internal solution contained (in $\mathrm{mM}$ ): $\mathrm{CsCl} 160 ; \mathrm{MgCl}_{2} 2$; HEPES 10; MgATP 2; $\mathrm{pH}$ adjusted to 7.4 with $\mathrm{CsOH}$. To this medium the following calcium chelators were added: 50-800 $\mu \mathrm{M}$ EGTA (Sigma) or BAPTA, $\mathrm{Cs}_{4}$ salt (Molecular Probes, Eugene, OR), as indicated in Results. The recording chamber was perfused continuously at a rate of $\sim 1.5 \mathrm{ml} / \mathrm{min}$, driven by air pressure, whereas the bath volume was kept constant by continuous suction. All experiments were performed at a temperature of $32-34^{\circ} \mathrm{C}$.

Capacitance measurements. Electrodes were pulled on a Flaming/Brown P-87 (Sutter Instruments, Novato, CA) horizontal microelectrode puller from thick-walled Clark GC-150 borosilicate glass (Clark Electromedical Instruments, Pangbourne, UK). To reduce the pipette capacitance, the tips of the electrodes were covered with Sylgard. Impedance of the electrodes after fire-polishing was 2-4 M $\Omega$, and the access resistance after establishment of the whole-cell configuration was $7.4 \pm 0.24 \mathrm{M} \Omega(n=75)$. The whole-cell membrane current was monitored with an Axopatch 200A amplifier (Axon Instruments, Foster City, CA) and digitized with a Digidata 1200 interface (Axon Instruments). Capacitance measurements were made using a software-based phase-sensitive detector (Joshi and Fernandez, 1988; Fidler and Fernandez, 1989; Fidler Lim et al., 1990). The source codes of the acquisition and analysis software, which run in an Axobasic environment (Axon Instruments), were acquired from Axon Instruments and modified in our laboratory (by P. F. van Soest and H. D. Mansvelder). A $40 \mathrm{mV}$ peak-to-peak, $1.2 \mathrm{kHz}$ sine wave was added to a holding potential of $-80 \mathrm{mV}$, and the resulting membrane current was filtered at $2 \mathrm{kHz}$ (4-pole low-pass Bessel filter on the Axopatch 200A) and sampled at 20 $\mathrm{kHz}$. Before analysis at two orthogonal phase angles, 10 cycles of the sine wave were averaged. The correct phase angle was determined every $18 \mathrm{sec}$ by repetitive computer-controlled switching of a $500 \mathrm{k} \Omega$ resistor in series with ground until changes in the capacitance trace were minimal. An independent measure of the membrane conductance was obtained by applying a hyperpolarizing pulse of $20 \mathrm{mV}$ and $6 \mathrm{msec}$ duration to the membrane between two groups of 10 sine waves (see Fig. 1A). The resulting temporal resolution of each capacitance, total conductance, and membrane conductance point was 18 milliseconds. In the experiments for Figures 10 and 11, the hyperpolarizing pulse between sine waves was omitted, thus leading to an enhanced temporal resolution of $10 \mathrm{msec}$. Changes in capacitance were calibrated by a temporary $100 \mathrm{fF}$ change in the compensation circuitry of the amplifier, and the conductance trace was calibrated by the $500 \mathrm{k} \Omega$ dither resistor. The initial membrane capacitance was $5.4 \pm 0.18 \mathrm{pF}$, and the average membrane conductance was $258 \pm 113$ $\mathrm{pS}$ (average of the mean $\pm \mathrm{SD}$ ).

Cells with a peak calcium current of less than $-50 \mathrm{pA}$ at the first pulse were left out of analysis. The number of calcium ions that entered the cell during a pulse was determined by:

$$
\frac{\int I_{C a}(t) d t}{2 \cdot F} \cdot N_{\mathrm{A}},
$$

where $F$ is Faraday's constant ( 96485 coulomb mol ${ }^{-1}$ ) and $N_{\mathrm{A}}$ is Avogadro's constant $\left(6.022 \cdot 10^{23} \mathrm{~mol}^{-1}\right)$. Tail currents were included in this integration. Leak currents were not corrected for.

Data analysis. The amount of exocytosis was calculated as the difference between the average of the last five membrane capacitance samples before and the first sample after a particular depolarizing pulse. The amount of endocytosis was calculated as the difference between the first sample after a pulse and the average of the last five samples before the next pulse. Monoexponential decays of the calcium currents and the endocytotic events at $50 \mu \mathrm{M}$ EGTA in Figure $6 A, B$ were fitted using the NLREG v3.4 software of P. H. Sherrod (Nashville, TN). Pairwise comparisons (with Bonferroni adjustment) in Figures $4 B, C, 5 B, C$, and $6 B, C$ were made using the Systat Software (Evanston, IL). The nonparametric correlation coefficient of Spearman (Spearman's $\rho$ ) was calculated for the data of Figure $6 C$ using the Simstat software of N. Péladeau (Montreal, Canada). Running averages of membrane conductance traces (see Fig. $1 B$ ) were calculated using software written by P. F. van Soest. Means mentioned in the text are given with SEM unless mentioned otherwise. Error bars represent SEM.

\section{RESULTS}

Changes in membrane capacitance were induced by interrupting the capacitance measurements and applying 25 step depolarizing pulses of $40 \mathrm{msec}$ from the holding potential $-80 \mathrm{mV}$ to $+10 \mathrm{mV}$ with an interval of $500 \mathrm{msec}$ (Fig. $1 B$ ). Capacitance measurements were resumed $\sim 15 \mathrm{msec}$ after the end of each pulse. By that time the membrane conductance had recovered to the level it had before the pulse (see both conductance traces in Fig. 1B), indicating that the first sample of the membrane capacitance $\left(\Delta C_{\mathrm{m}}\right)$ after the pulse is reliably measured. The depolarizing pulses were evoked 5 min after establishment of the whole-cell configuration to allow equilibration of the intracellular medium and pipette solution. The average peak whole-cell calcium current generated by the first pulse of each series was $-127 \pm 38 \mathrm{pA}$ (mean $\pm \mathrm{SD} ; n=72$ ) (Fig. $1 B$ ). Inactivation during these current responses was adequately described by monoexponential functions fitted to the decay phase of the current, yielding an average time constant of $13.9 \pm 3.6 \mathrm{msec}$ and an asymptote $\left(I_{\infty}\right)$ of $-50 \pm$ $26 \mathrm{pA}$ (both mean $\pm \mathrm{SD}$; fits not shown). This time constant is approximately seven times faster than the inactivation time constant of the Q-type current found in these cells at room temperature and with barium as charge carrier $(101.7 \pm 28.4 \mathrm{msec}$; mean \pm SD) (Mansvelder et al., 1996).

\section{Short step depolarizations trigger fast exocytosis}

First we determined what types of exocytosis were evoked by the $40 \mathrm{msec}$ step depolarizations. In the majority of cells $(>93 \%)$ that we recorded from, the capacitance increase was already complete when the step depolarization had ended, and no further increase was observed (see capacitance trace in Fig. 1B). Most of the time the $\Delta C_{\mathrm{m}}$ trace decreased a little after the initial increase after the pulse $(-2.3 \pm 0.22 \mathrm{fF} ; n=13$ cells) (Fig. $2 A)$. In chromaffin cells, Chow et al. (1992) found that although the capacitance trace ceased to increase as soon as the depolarization was ended, the amperometric events continued for tens of milliseconds, suggesting that exocytosis was still taking place without any apparent change in membrane capacitance. The apparent difference was explained by transient changes in the capacitance trace that were not related to exocytosis (Horrigan and Bookman, 1994). When the capacitance traces were corrected for these events, a slow increase in membrane capacitance appeared that was in agreement with the amperometric record (Chow et al., 1996). We tested whether a nonsecretory capacitive transient contaminated the capacitance measurements in our experiments, by depolarizing cells in the presence of $100 \mu \mathrm{M} \mathrm{Cd}{ }^{2+}$ to block the calcium influx. We assume that by blocking the calcium influx, 
A

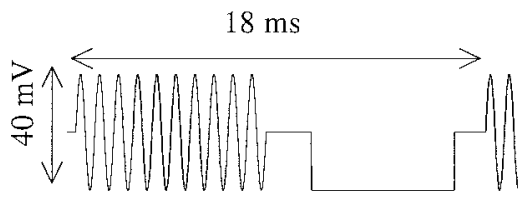

\section{B}
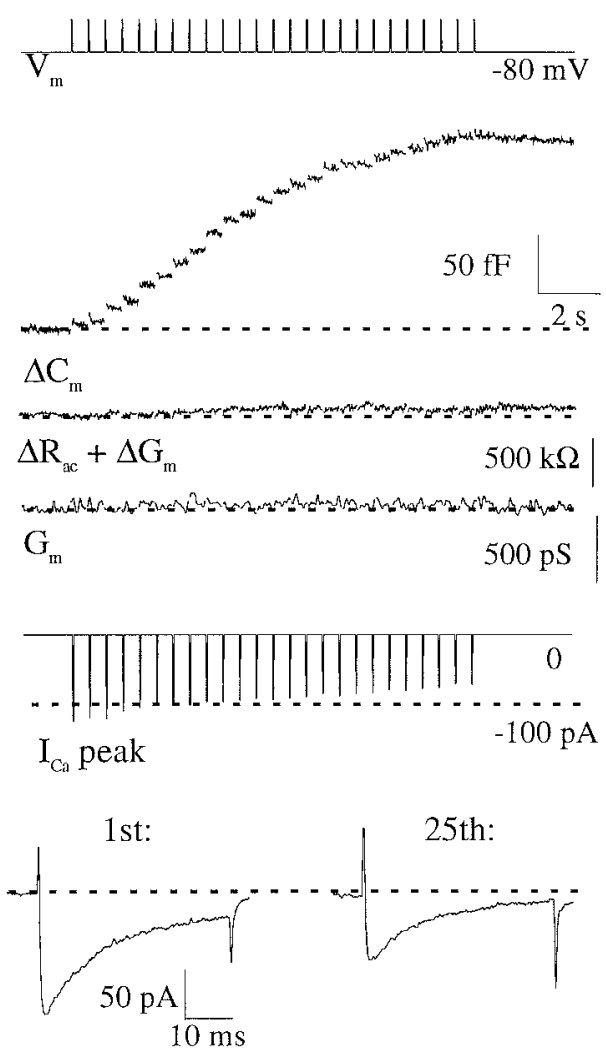

Figure 1. Voltage command protocols applied to the cell to monitor $\Delta C_{\mathrm{m}}, \Delta R_{\mathrm{ac}}$, and $\Delta G_{\mathrm{m}}$ and to evoke $I_{\mathrm{Ca}} \cdot A$, Protocol used to acquire one sample of the capacitance trace $\left(\Delta C_{\mathrm{m}}\right)$, conductance trace $\left(\Delta R_{\mathrm{ac}}\right.$ and $\left.\Delta G_{\mathrm{m}}\right)$, and membrane conductance trace $\left(G_{\mathrm{m}}\right)$. Ten cycles of a sinusoidal voltage command of $1200 \mathrm{~Hz}$ were averaged for one sample of $\Delta C_{\mathrm{m}}$ and the combined $\Delta R_{\mathrm{ac}}$ and $\Delta G_{\mathrm{m}}$. A $6 \mathrm{msec}$ hyperpolarization yielded an independent measure of the cell conductance. The current response of the cell was filtered at $2 \mathrm{kHz}$ with the low-pass Bessel filter on the amplifier, digitized, and analyzed on-line. B, Top trace, Voltage command trace $\left(V_{\mathrm{m}}\right)$ shown on a larger time scale. The sinusoidal was omitted for the sake of simplicity. Depolarizing pulses were applied every $500 \mathrm{msec}$ from -80 to $+10 \mathrm{mV}$. Middle traces, The response to the 25 step depolarizations. $\Delta C_{\mathrm{m}}$, combined $\Delta R_{\mathrm{ac}}$ and $\Delta G_{\mathrm{m}}$ trace, and membrane conductance trace were obtained with the protocol in $A$. The $G_{\mathrm{m}}$ trace is a 5 points running average. Bottom traces, Peak calcium $\left(I_{C a}\right.$ peak) current during the $40 \mathrm{msec}$ step depolarization. Below, the full current traces are given for the 1st and 25th pulse. [EGTA] $]_{\mathrm{i}}=200 \mu \mathrm{M}$.

depolarization-induced exocytosis is prevented, and any further change in $\Delta C_{\mathrm{m}}$ is not related to exocytosis or endocytosis. In the

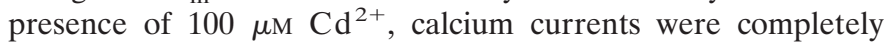
blocked (not shown). Still, an increase in capacitance of $2.3 \pm$ $0.20 \mathrm{fF}$ (average of 225 depolarizations in three cells) was detected right after the pulse, and the capacitance successively decreased within $\sim 35 \mathrm{msec}$ by $-1.1 \pm 0.21 \mathrm{fF}$ (Fig. $2 B$ ). Correction of the $\Delta C_{\mathrm{m}}$ record by subtraction of the records in the presence of $\mathrm{Cd}^{2+}$ showed that the $\Delta C_{\mathrm{m}}$ trace did not increase any further after the end of the depolarization (Fig. 2C). This suggests that exocytosis is complete at the end of the pulse and that a $40 \mathrm{msec}$ depolarization only triggers fast exocytosis. However, we cannot exclude the occurrence of slow exocytosis after the pulse that is counterbalanced by the retrieval of the same amount of membrane (see also Discussion). To quantify exocytosis in the rest of the paper we have taken the difference between the membrane capacitance before the depolarization and the first $\Delta C_{\mathrm{m}}$ sample immediately after the depolarization (see Materials and Methods). Furthermore, all quantifications of exocytosis and endocytosis that follow below are corrected for the $\mathrm{Cd}^{2+}$. insensitive transient, discussed above. This method yields the net amount of exocytosis occurring during and after the depolarization and will be an underestimation of the actual amount of exocytosis if any endocytosis occurs simultaneously.

The average amount of exocytosis that was elicited by a step depolarization was $7.8 \pm 0.41 \mathrm{fF}$, which corresponds to $\sim 3 \%$ of the immediately releasable pool revealed by flash photolysis of caged $\mathrm{Ca}^{2+}$ in these cells (Thomas et al., 1993a; Parsons et al.,. 1995). Obviously, a short opening of calcium channels leads to a completely different calcium profile underneath the membrane than a uniform rise throughout the cell, and as a result, single step depolarizations recruit only a small fraction of the total releaseready vesicle pool.

During the 25 depolarizing pulses the peak calcium current declined steadily from $-127 \pm 38$ at the first pulse to $-79 \pm 24$ $\mathrm{pA}($ mean $\pm \mathrm{SD})$ at the last pulse (Fig. $1 B$ ). As a result, the number of calcium ions that came into the cell during a step depolarization decreased as well. At the first depolarization $9.5 \pm$ $3.410^{6}$ ions entered the cell, whereas at the last pulse $5.5 \pm 2.1$ $10^{6}$ ions entered. At the same time, the amount of exocytosis per pulse decreased steadily during the pulse train (Fig. $3 A$ ). When the amount of exocytosis per pulse was corrected for the diminished calcium influx, thus calculating $\Delta C_{\mathrm{m}}$ per number of calcium ions that entered the cell, the decrease was almost absent (Fig. $3 B$ ). This indicates that the reduction in exocytosis per pulse at the end of the pulse train can be largely explained by a diminished calcium influx at the later pulses.

\section{Calcium chelator EGTA affects fast exocytosis at low concentrations}

We asked whether voltage-gated calcium channels are located close to release-ready vesicles or whether calcium ions have to diff use a large distance. To answer this question we increased the intracellular buffer capacity by increasing the concentration of the calcium chelator EGTA, thereby reducing the chance that a calcium ion reaches the vesicle at a certain distance. Changing the concentration of a diff usable calcium buffer with a slow forward binding constant like EGTA has only limited effects on the peak calcium concentration just beneath the site of influx, but is more effective on calcium levels farther away from this point (Nowycky and Pinter, 1993; Roberts, 1994).

When the EGTA concentration was raised, the total amount of $\Delta C_{\mathrm{m}}$ after 25 pulses was significantly decreased from $257 \pm 63 \mathrm{fF}$ at $50 \mu \mathrm{M}(n=8)$ to $175 \pm 22 \mathrm{fF}$ at $100 \mu \mathrm{M}$ and $183 \pm 37 \mathrm{fF}$ at 200 $\mu \mathrm{M}$ (both $n=13$ ) (Fig. $4 A, D$ ). When the EGTA concentration was further increased to $400 \mu \mathrm{M}$, exocytosis was reduced more dramatically to $83 \pm 9 \mathrm{fF}$ at $400 \mu \mathrm{M}(n=9)$ and $48 \pm 19 \mathrm{fF}$ at 800 $\mu \mathrm{M}(n=5)$. The amount of exocytosis per pulse decreased significantly from $10.3 \pm 0.54 \mathrm{fF}$ at $50 \mu \mathrm{M}$ EGTA to $1.9 \pm 0.20 \mathrm{fF}$ at $800 \mu \mathrm{M}$ (Fig. 4B). We corrected these values for differences in calcium entry between cells and pulses (Fig. 4C). From this it 


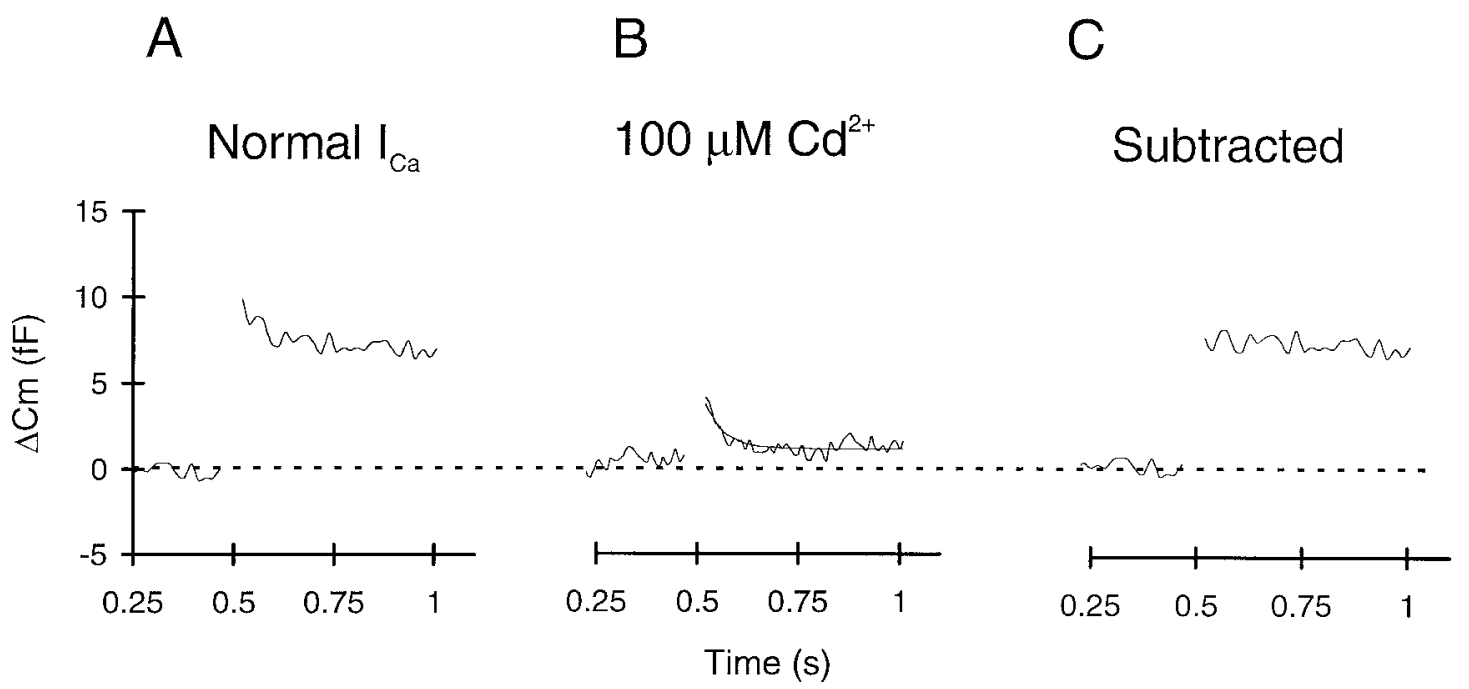

Figure 2. Exocytosis does not persist after calcium entry has stopped. $A$, Average of responses to 25 step depolarizations $\left([\mathrm{EGTA}]_{\mathrm{i}}=200 \mu \mathrm{M}\right)$. $B$, Average transient capacitance change in the presence of $100 \mu \mathrm{M} \mathrm{Cd}^{2+}$, to block the calcium influx (average response to 75 depolarizations of one cell). Solid line shows a single exponential fit to the decay of the average capacitance transient. Data were obtained from a cell different from that in $A$ ([EGTA $]_{\mathrm{i}}$ $=50 \mu \mathrm{M})$. The average of three such experiments on different cells was used to correct all quantifications of exocytosis and endocytosis throughout this study. There were no significant differences between the three cells, and they were all stimulated with 75 depolarizations. $C$, The solid line of $B$ is subtracted from the $\Delta C_{\mathrm{m}}$ trace in $A$, to give the $\Delta C_{\mathrm{m}}$ that is caused by exocytosis.

\section{A}

Figure 3. The decrease of $\Delta C_{\mathrm{m}}$ during the pulse train can be attributed to a decrease of calcium influx. $A$, Average $\Delta C_{\mathrm{m}}$ response per pulse during the pulse train. The amount of $\Delta C_{\mathrm{m}}$ per pulse decreased during the pulse train. The pipette solution contained $100 \mu \mathrm{M}$ EGTA $(n=13$ cells $) . B$, Same data as in $A$ but now every capacitance jump is divided by the number of calcium ions that came into the cell during the step depolarization. The number of calcium ions is determined by integrating the current trace, as described in Materials and Methods. The efficacy of calcium ions to stimulate exocytosis showed almost no attenuation during the pulse train.

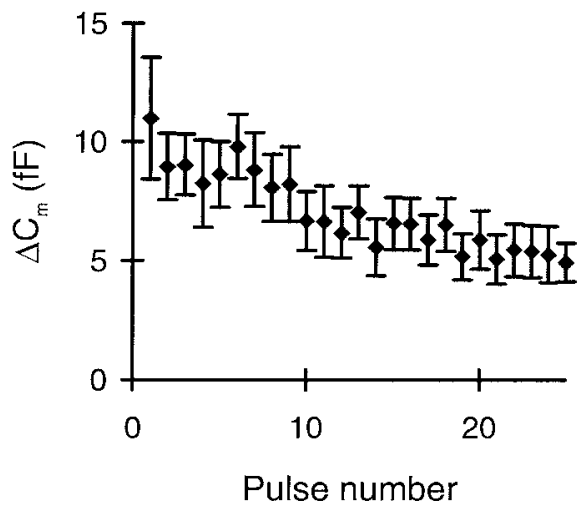

Pulse number
B

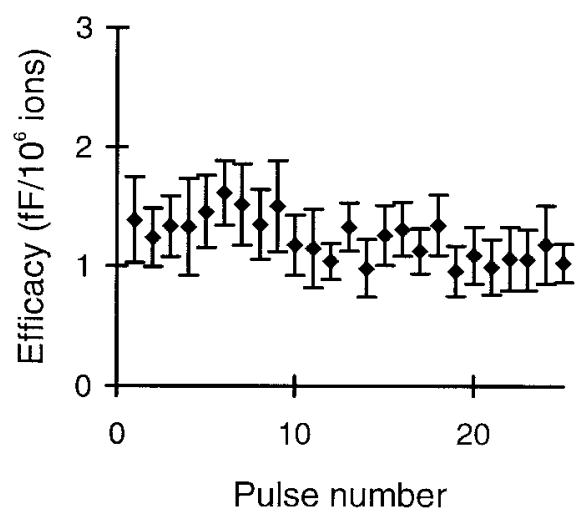

became evident that the efficacy of calcium ions to stimulate exocytosis was only slightly reduced at 100 and $200 \mu \mathrm{M}$ EGTA but was especially hampered at 400 and $800 \mu \mathrm{M}$ EGTA $(p<0.01)$. Figure $4 D$ shows that the membrane capacitance increased approximately linearly with the cumulative number of calcium ions that came into the cell during the pulse train. There was no threshold of a minimal number of calcium ions needed to start exocytosis at $40 \mathrm{msec}$ pulse durations, in contrast to what was found in chromaffin cells (Seward et al., 1995) and peptidergic nerve terminals (Seward and Nowycky, 1996). Increasing EGTA concentrations did not introduce a calcium threshold of secretion; instead, it mainly decreased the slope of these plots, and this effect became most prominent at 400 and $800 \mu \mathrm{M}$ (Fig. 4D). So, fast exocytosis of predocked vesicles is suppressed at relatively low concentrations of EGTA, suggesting that calcium ions have to diffuse a large distance from the site of influx to the calcium sensor of the exocytotic complex in melanotropes. Given this large distance, the calcium concentration that is sensed by a predocked vesicle most likely results from the entry of calcium through multiple calcium channels.

\section{BAPTA is only twice as effective as EGTA}

The calcium chelator BAPTA has a forward calcium binding constant that is $\sim 100$ times faster than EGTA, while at the same time the $K_{\mathrm{D}}$ for calcium is $\sim 100 \mathrm{~nm}$ at $\mathrm{pH} 7.3$ for both (Tsien, 1980; Smith et al., 1984). Given these properties, BAPTA should be $\sim 100$ times more effective in blocking exocytosis in melanotropes, if calcium only has to diff use from its site of entry to the calcium sensor of the exocytotic complex in the immediate vicinity. However, when the pipette solution contained $50 \mu \mathrm{M}$ BAPTA instead of EGTA, exocytosis still was possible (Fig. $5 A$ ). The total amount of $\Delta C_{\mathrm{m}}$ after 25 depolarizations was $168 \pm 36 \mathrm{fF}$ at $50 \mu \mathrm{M}$ BAPTA $(n=10)$ (Fig. 5A,D), which was not significantly different from the amount of exocytosis at 100 and $200 \mu \mathrm{M}$ EGTA. At 200 $\mu \mathrm{M}$ BAPTA, the membrane capacitance increased by $116 \pm 46$ $(n=5)$, which was not significantly different from the change seen 


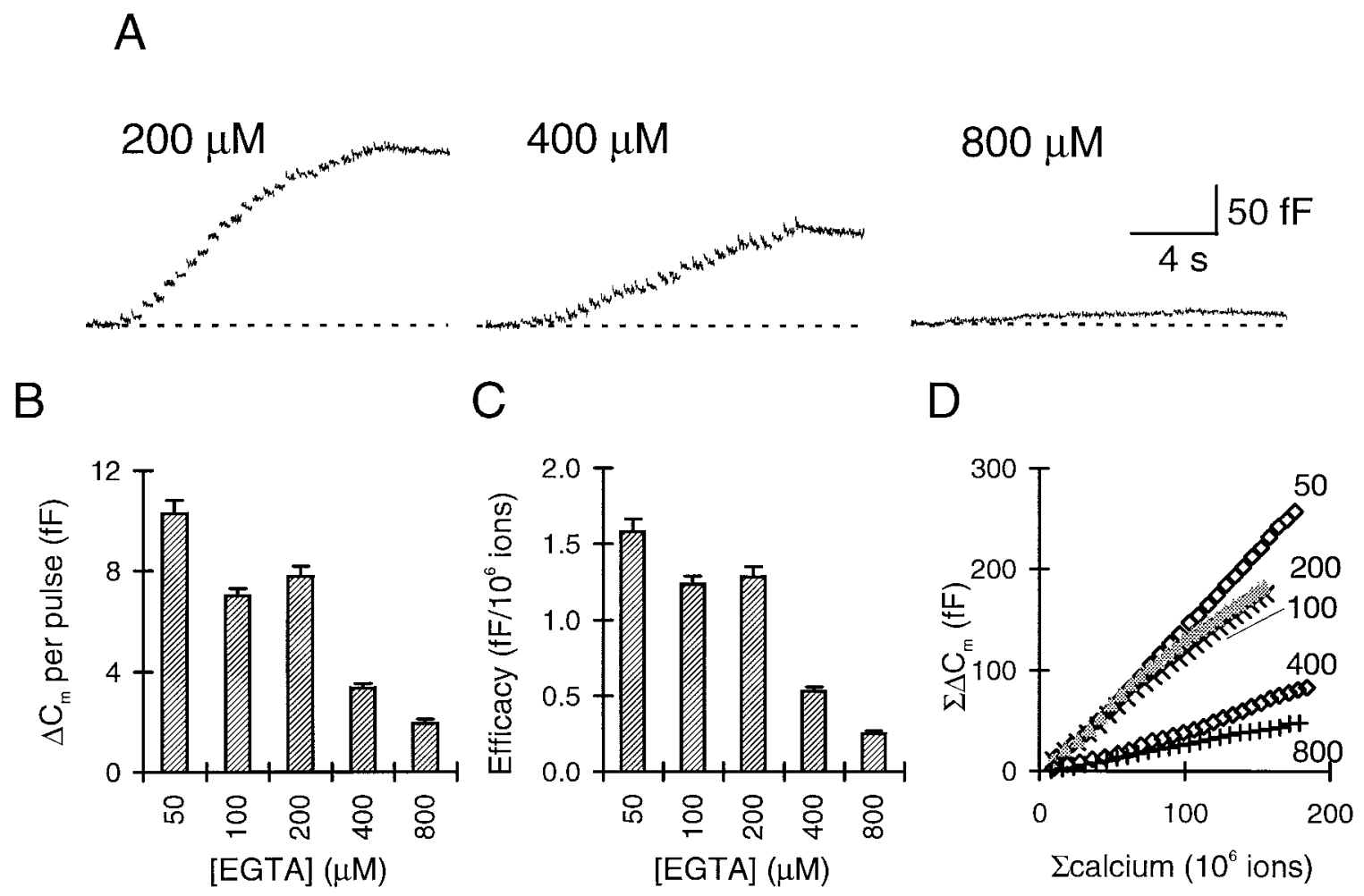

Figure 4. Exocytosis is affected by low concentrations of EGTA. A, Examples of responses to 25 step depolarizations with different EGTA concentrations as indicated next to the traces. For every experiment a new cell was taken. The noise in the $800 \mu \mathrm{M}$ trace (SD of $1.72 \mathrm{fF}$ ) was somewhat lower than in the other two traces (SD of $2.26 \mathrm{fF}$ at $200 \mu \mathrm{M}$ ), but the values are within the normal variation encountered in both groups $[2.25 \pm 0.60$ $\mathrm{fF}$ at $800 \mu \mathrm{M}$ and $2.24 \pm 1.12 \mathrm{fF}$ at $200 \mu \mathrm{M}$ (both mean $\pm \mathrm{SD} ; P>0.9$ )]. $B$, The average $\Delta C_{\mathrm{m}}$ per depolarization at different EGTA concentrations. $C$, Efficacy of calcium ions to stimulate exocytosis at different EGTA concentrations. Pairwise comparisons showed that the amount of exocytosis at 100 and $200 \mu \mathrm{M}$ did not differ significantly; all other groups differed significantly from each other $(p<0.01)$. $D$, Cumulative capacitance change plotted versus the cumulative number of calcium ions that came into the cell during a pulse train. These curves showed almost straight lines with different slopes for the different EGTA concentrations. The numbers next to each curve represent the intracellular EGTA concentration in micromoles. For $B, C$, and $D$ : $50 \mu \mathrm{M}, n=8 ; 100 \mu \mathrm{M}, n=13 ; 200 \mu \mathrm{M}, n=13 ; 400 \mu \mathrm{M}, n=10 ; 800 \mu \mathrm{M}, n=5$.

at $400 \mu \mathrm{M}$ EGTA. The average amount of exocytosis per pulse decreased from $6.7 \pm 0.5 \mathrm{fF}$ to $4.6 \pm 0.5 \mathrm{fF}$ per pulse $(p<0.01)$ when BAPTA was raised from 50 to $200 \mu \mathrm{M}$ (Fig. 5B). Correction for the number of calcium ions that came into the cells during a pulse showed that the average efficacy of calcium ions to stimulate exocytosis decreased from $1.15 \pm 0.07 \mathrm{fF} / 10^{6}$ calcium ions to $0.7 \pm 0.07 \mathrm{fF} / 10^{6}$ calcium ions $(p<0.01)$ (Fig. $\left.5 C\right)$. No threshold secretion was observed using BAPTA as the mobile calcium chelator (Fig. 5D). As with EGTA, increasing BAPTA concentrations affected the slope of cumulative $\Delta C_{\mathrm{m}}$ versus cumulative calcium plot. Taken together, these data show that although BAPTA is 100 times faster than EGTA in binding calcium ions, it is only approximately twice as effective as EGTA in blocking exocytosis in melanotropes. Possibly the distance that calcium ions have to travel before reaching the predocked vesicle is so large that the binding kinetics of the soluble chelator is less important than the $K_{\mathrm{D}}$ for calcium. These data support the idea that influx of calcium through multiple calcium channels will contribute to the concentration sensed by the predocked vesicle.

\section{Rapid endocytosis is more sensitive to calcium buffering capacity than exocytosis}

When the EGTA concentration in the pipette solution was set to $50 \mu \mathrm{M}$, a rapid decrease of membrane capacitance was seen right after each depolarization (Fig. 6A). We interpreted these deflections as rapid membrane retrieval as described by Thomas et al.
(1994). The amount of endocytosis was determined as the difference between the first sample after the pulse and the average of the last five samples before the next pulse (see Material and Methods). Again, as with quantifying exocytosis, this method calculates the net amount of endocytosis and therefore might underestimate the actual values if exocytosis occurs concomitantly. The total amount of membrane that was retrieved after 25 step depolarizations was $237 \pm 68 \mathrm{fF}(n=8)$ (Fig. $6 D)$, and only slightly more $(257 \pm 63 \mathrm{fF}$; see above) was added during the same 25 pulses. As a result, after a few pulses the net membrane capacitance did not increase any further (Fig. 6 $A$ ). Excess retrieval, which was observed by Thomas et al. (1994) using flash photolysis of caged calcium, was only rarely observed, and when it occurred it exceeded the amplitude of exocytosis at the same pulse by only a few femtofarads.

When the intracellular EGTA concentration was raised to 100 $\mu \mathrm{M}$, rapid membrane retrieval almost completely disappeared $(p<0.01)$ (Fig. 6A,D). At this EGTA concentration only $61 \pm 27$ $\mathrm{fF}$ was retrieved during the pulse train. The amount of endocytosis per pulse decreased from $9.5 \pm 0.57 \mathrm{fF}$ at $50 \mu \mathrm{M}$ EGTA to $2.4 \pm 0.19 \mathrm{fF}$ at $100 \mu \mathrm{M}(p<0.01)$, and this was more or less the same for all higher concentrations of EGTA up to $800 \mu \mathrm{M}$ (Fig. $6 B)$. When these amounts of membrane retrieval were corrected for the amount of calcium influx during the pulse, the picture was the same (Fig. 6C). At all EGTA concentrations of $100 \mu \mathrm{M}$ and 


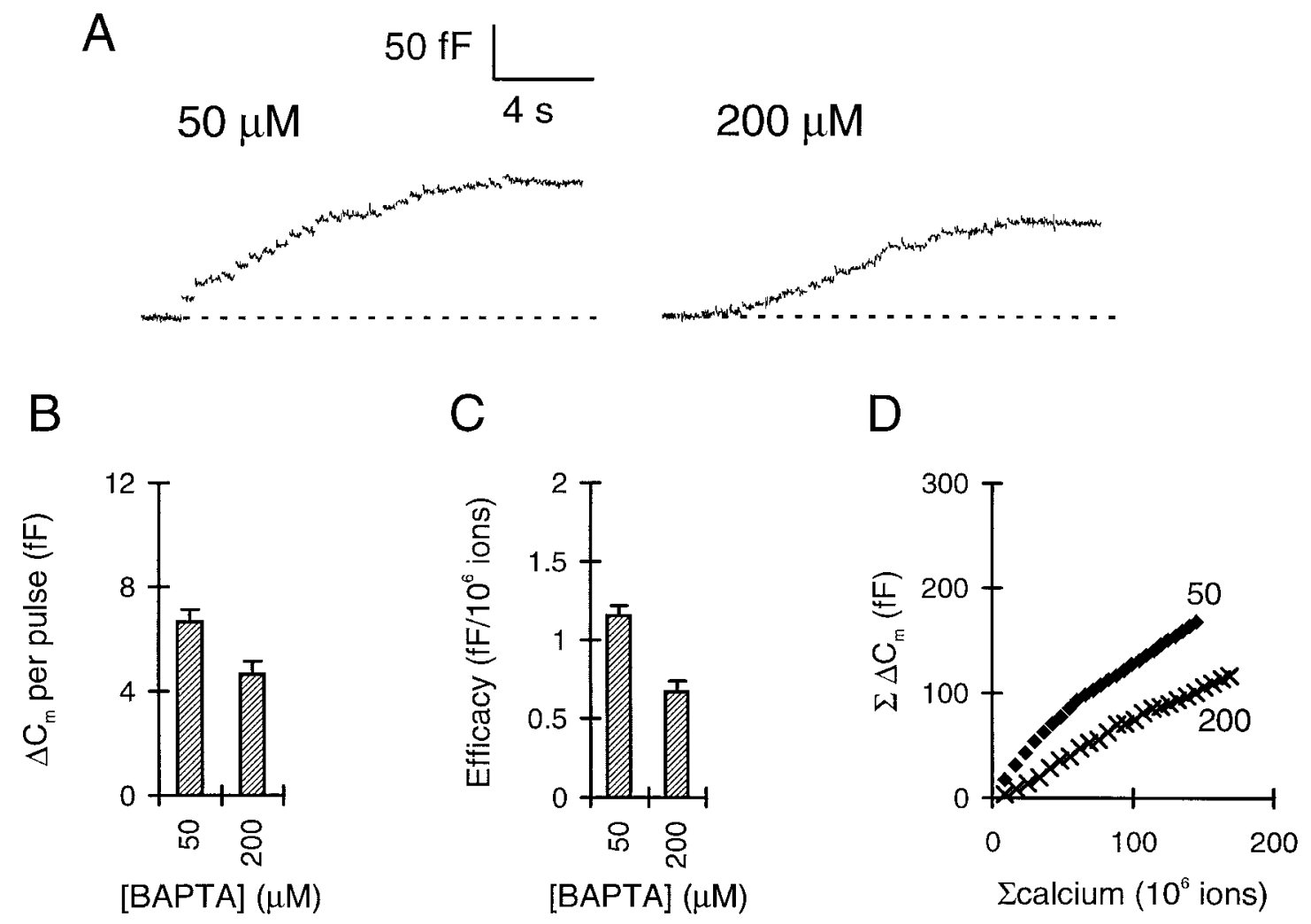

Figure 5. Exocytosis is still possible with 50 and $200 \mu \mathrm{M}$ intracellular BAPTA. A, Examples of responses on two different cells with BAPTA concentrations indicated. $B$, Average $\Delta C_{\mathrm{m}}$ per depolarization at the two different BAPTA concentrations. $C$, Efficacy of calcium ions to stimulate exocytosis per pulse. Pairwise comparisons showed that the efficacy at $50 \mu \mathrm{M}$ BAPTA was not significantly different from the efficacy at 100 and $200 \mu \mathrm{M}$ EGTA $(p>0.1)$ (Fig. $4 C)$. The efficacy at $200 \mu \mathrm{M}$ BAPTA was not significantly different from the efficacy at $400 \mu \mathrm{M}$ EGTA (Fig. 4C). $D$, Cumulative capacitance change plotted versus the cumulative number of calcium ions that came into the cell during a pulse train. These curves deviated slightly from straight lines, with a lower slope at later pulses; still, the different BAPTA concentrations clearly show different slopes. The numbers represent the intracellular BAPTA concentration in micromoles. For $B, C$, and $D: 50 \mu \mathrm{M}, n=10 ; 200 \mu \mathrm{M}, n=5$.

higher endocytosis is depressed. These results confirm first of all that endocytosis in melanotropic cells is calcium dependent. Second, because exocytosis was depressed at approximately five times higher EGTA concentrations than endocytosis (compare Figs. 4 and 6), these results indicate that either the $K_{\mathrm{D}}$ for calcium is higher for endocytosis than for exocytosis or that calcium ions have to travel a larger distance from the site of influx to the sensor for the endocytotic process than for the exocytotic process.

\section{Efficacy of calcium ions to stimulate endocytosis increases slowly during the pulse train}

As the example with $50 \mu \mathrm{M}$ EGTA in Figure $6 \mathrm{~A}$ showed, the amplitude of endocytosis increased during the pulse train, and after a few depolarizations the amplitude of endocytosis matched the amplitude of exocytosis. This is shown for the average amplitude of endocytosis per pulse in Figure $7 A$. At the first pulse, $<5 \mathrm{fF}$ membrane was retrieved but the amplitude increased, and at the fourth pulse already more than $10 \mathrm{fF}$ was retrieved. The fitted line is a single exponential with a time constant of $0.5 \mathrm{sec}$. At the same time, the amount of calcium that entered the cell during the pulse decreased with increasing pulse number (Fig. $1 B)$. As a result, the efficacy of calcium ions to stimulate endocytosis continued to increase after the amplitude of endocytosis reached its maximum during the pulse train (Fig. $7 B$ ). The single exponential fitted to the data in Figure $7 B$ had a time constant of $2.3 \mathrm{sec}$. It took $\sim 10$ pulses to reach an efficacy that corresponded to the efficacy of exocytosis at the same pulse $(-1.7 \pm 0.3$ vs $1.5 \pm$
$0.3 \mathrm{fF} / 10^{6}$ calcium ions) (Fig. $4 C$ ). So, the amount of endocytosis that is triggered by a given number of calcium ions that came into the cell during a pulse increases during the pulse train with a time constant of seconds. This might suggest that a slow step is involved in membrane retrieval that takes a few seconds.

\section{The rate of rapid endocytosis is constant during a pulse train}

To determine whether the rate of membrane retrieval increased during the pulse train as well, we fitted monoexponential decay functions to the decreases in membrane capacitance immediately after each depolarization (see example in the inset of Fig. 8). Not all endocytotic responses could be fitted with an exponential decay function; some of them showed a more linear decay. Moreover, because the pulses were set apart in time by only $500 \mathrm{msec}$, fits of exponential decays with a time constant larger than 250 msec were considered as not reliable. Still, $\sim 64 \%$ of the endocytotic responses (127 of 200 in eight cells) showed a monoexponential decay with a time constant below $250 \mathrm{msec}$. Figure 8 shows the average time constant per pulse number, with each data point showing the average of three to eight responses obtained from different cells. The time constant of membrane retrieval did not change with increasing pulse number, and the overall average was $116 \pm 5 \mathrm{msec}$ (Fig. 8). This is approximately three times faster than the $350 \mathrm{msec}$ time constant of fastest retrieval measured at room temperature by Thomas et al. (1994). Although the amplitude and efficacy of endocytosis grow with increasing pulse num- 
A $50 \mu \mathrm{M}$

$\Delta$

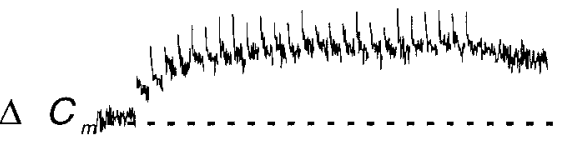

$\Delta R_{\text {ac }}$

$\Delta G_{m}$

$G_{m}$

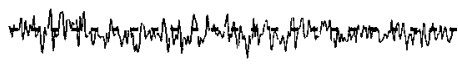
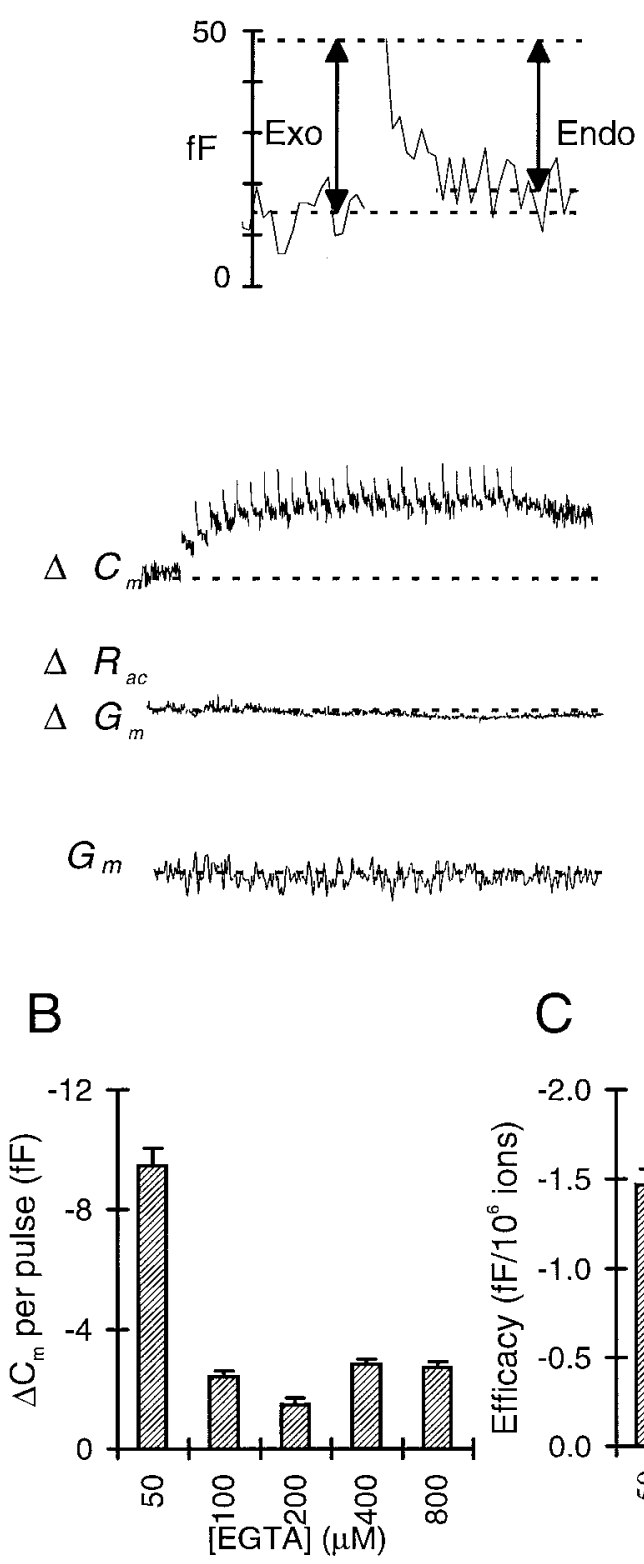
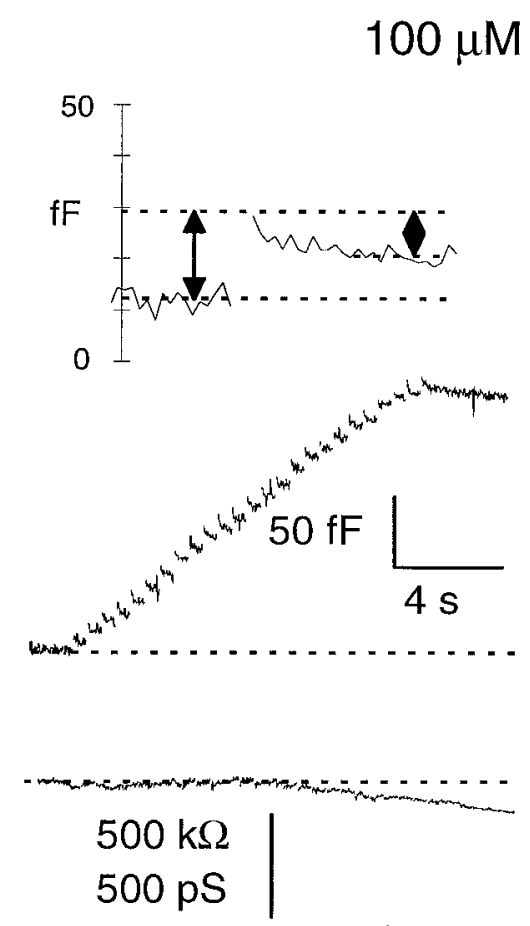

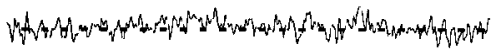

Figure 6. Rapid endocytosis is blocked by a lower concentration of EGTA than exocytosis. $A$, Examples of $\Delta C_{\mathrm{m}}$ responses of two different cells to 25 step depolarizations with 50 and $100 \mu \mathrm{M}$ intracellular EGTA. At $100 \mu \mathrm{M}$ intracellular EGTA, with each pulse $C_{\mathrm{m}}$ increases, and only small decreases are seen after each pulse. At $50 \mu \mathrm{M}$ EGTA, $C_{\mathrm{m}}$ decreases rapidly after each increase (see inset), so that the net $C_{\mathrm{m}}$ increases only $\sim 50 \mathrm{fF}$. The combined $\Delta R_{\mathrm{ac}}$ and $\Delta G_{\mathrm{m}}$ traces and the $G_{\mathrm{m}}$ traces are depicted to show that there was no significant cross-talk between the traces. The top panels illustrate the method that was used to calculate the amount of exocytosis (Exo) and endocytosis (Endo). The same method was used for Figures 7 and 9.8 , Average amount of $C_{\mathrm{m}}$ that is retrieved after each step depolarization. Rapid endocytosis is depressed at $100 \mu \mathrm{M}$ EGTA. $C$, The efficacy of calcium ions to stimulate rapid endocytosis. Obviously, the efficacy is also depressed at $100 \mu \mathrm{M}$ EGTA $(p<0.01)$. $D$, Cumulative $C_{\mathrm{m}}$ that is retrieved during a pulse train versus the cumulative number of calcium ions that came into the cell during the pulse train. The slope of the 100 $\mu \mathrm{M}$ EGTA curve (labeled 100) is much lower than the slope at $50 \mu \mathrm{M}$ (labeled 50). For $B, C$, and $D$, the data from the same cells as in Figure 4 were used.

ber (Fig. 7), the fact that the average time constant did not change with increasing pulse number suggests that once the process of endocytosis is triggered it proceeds at a fixed rate.

\section{Fast exocytosis and rapid endocytosis are strongly coupled processes}

During the pulse train the amplitude of endocytosis increased, and after a few pulses it matched the amplitude of exocytosis (Fig. 6A). As a result the net $C_{\mathrm{m}}$ did not increase further. In Figure 9 the amplitude of endocytosis after a given pulse is plotted against the amplitude of exocytosis caused by the same pulse for all 200 pulses. The amplitude of endocytosis showed a strong correlation with the amplitude of exocytosis (Fig. 9), with a correlation coefficient of 0.80 (Spearman's $\rho$; $p<0.01$ ). This suggests that the cell retrieves just as much membrane as has been added during a step depolarization, thereby actively keeping its membrane area constant. Together with the fast time constant of membrane retrieval, the strong correlation between the amplitudes of exocytosis and endocytosis supports 
A

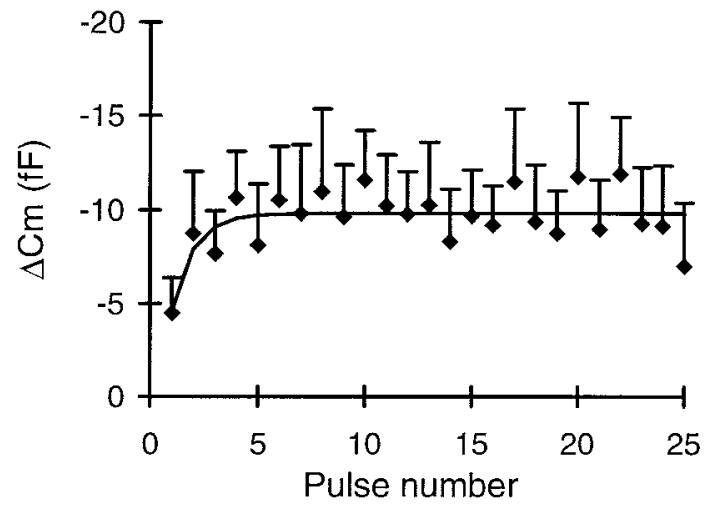

B

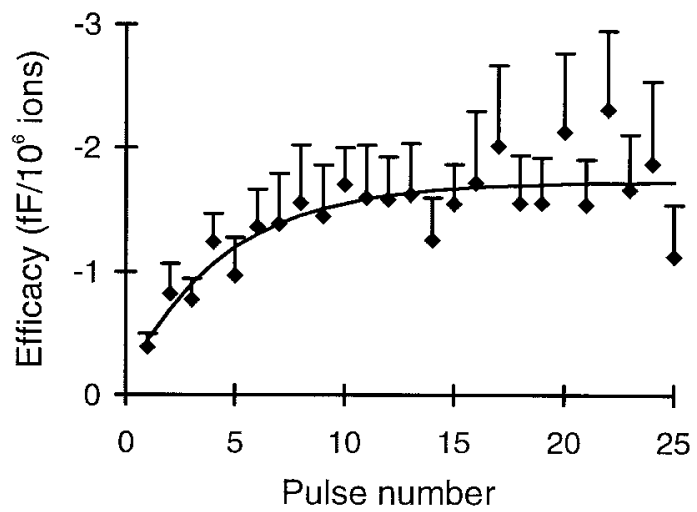

Figure 7. Efficacy of calcium ions to stimulate endocytosis increases slowly during the pulse train. $A$, Average amplitude of rapid endocytosis per pulse number. Data from the cells as in Figures 4 and 6, with an intracellular EGTA concentration of $50 \mu \mathrm{M}(n=8)$. The amplitude of rapid endocytosis was measured as indicated in Materials and Methods. The solid line represents a fitted single exponential function with a time constant of 0.5 sec. $B$, Average efficacy of calcium ions to stimulate rapid endocytosis per pulse number. The efficacy increases during the pulse train, with a time constant of 2.3 sec (solid line).

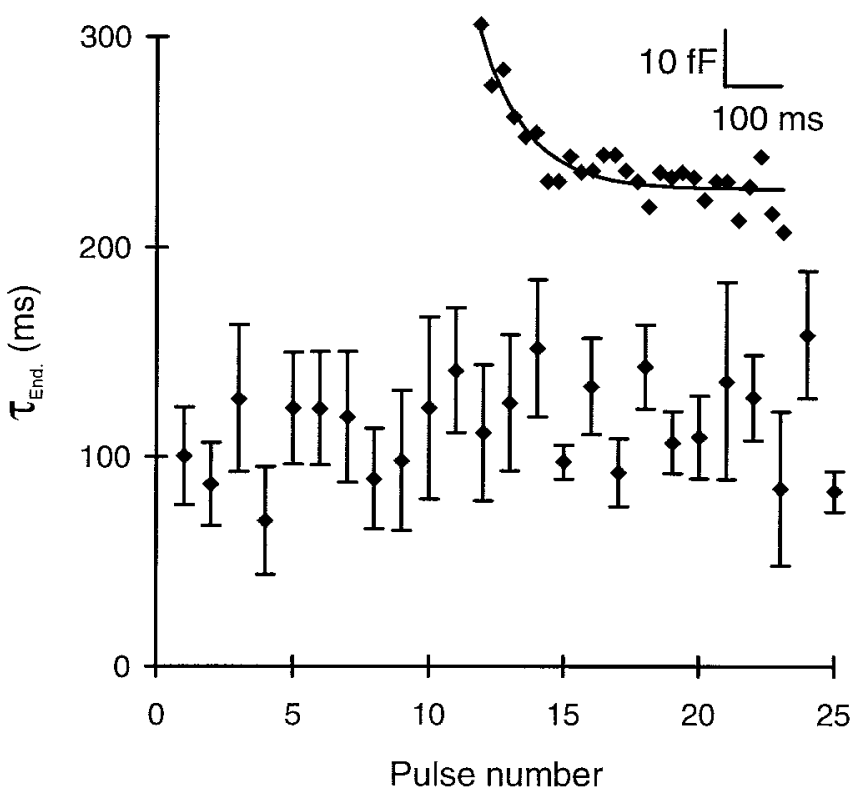

Figure 8. The time constant of rapid endocytosis is constant during a pulse train. A single exponential function was fitted to the decay in membrane capacitance occurring immediately after the depolarizations (inset). Each decrease after a given pulse was fitted this way, and the time constants were averaged for each particular pulse number $(n=8$ cells, each subjected to 1 pulse train). When a decrease could not be reliably fitted, it was left out of the average. As mentioned in the text, 127 of the 200 endocytotic responses could be reliably fitted with an exponential decay function. There was no relation found between the number of acceptable fits underlying each average and the number of the pulse in the pulse train. The plot shows the average time constant of membrane capacitance decrease as a function of pulse number.

the idea that it is the exocytotic vesicle itself that is retrieved rapidly, immediately after fusion.

\section{Exocytosis increases linearly with the duration of calcium influx}

Because the mobile calcium buffering capacity of the intracellular medium affects exocytosis at low concentrations, the distance between the site of calcium influx and the site of release must be considerably large. From this it might be inferred that a single spike lasting a few milliseconds is probably not capable of triggering any secretion, and that the melanotropic cell is only able to regulate to a limited extent the timing of release in comparison with neuronal synapses. On the other hand, if calcium channel and vesicle are far apart, one would expect that melanotropic cells would show threshold secretion, as was found for chromaffin cells and peptidergic nerve terminals (Seward et al., 1995; Seward and Nowycky, 1996); however, this was not found at $40 \mathrm{msec}$ depolarizations (Figs. 4D, 5D). Thus, we asked how well exocytosis couples to the calcium current in the melanotropic cell. We applied 15 step depolarizations at $2 \mathrm{~Hz}$ with varying pulse durations from $2 \mathrm{msec}$ up to $40 \mathrm{msec}$. For these experiments we used $50 \mu \mathrm{M}$ EGTA in the pipette solution, thus allowing rapid endocytosis, because Thomas et al. (1994) showed that rapid retrieval occurs in perforated patch recordings from melanotropes, in which the endogenous buffer system is intact.

With increasing pulse durations the total capacitance increase became larger (Fig. 10). With $2 \mathrm{msec}$ depolarizations the membrane capacitance increased by $0.83 \pm 0.15 \mathrm{fF}$ per pulse (average of 120 depolarizations on eight cells). This is approximately the estimated capacitance of one large dense-cored vesicle in melanotropes (Parsons et al., 1995), suggesting that, on average, at 2 msec step depolarizations one vesicle is released. The bottom plots of Figure 10 show the average cumulative $\Delta C_{\mathrm{m}}$ of eight cells against the cumulative number of calcium ions that came into the cell during the pulse train. As for the $40 \mathrm{msec}$ pulses shown above (Fig. 4D), the curves show an approximately straight line for shorter pulse durations as well. Interestingly, the slope of the curves is almost the same for all pulse durations.

With increasing pulse duration the amplitude of exocytosis increased, as well as the inactivation of the calcium current during a pulse and over 15 pulses (Fig. 10). The amplitude of exocytosis per pulse increased from $1.95 \pm 0.25 \mathrm{fF}$ at $5 \mathrm{msec}$ to $7.21 \pm 0.38$ $\mathrm{fF}$ at $40 \mathrm{msec}(n=8)$. The total amount of exocytosis after 15 pulses is plotted against pulse duration in Figure $11 \mathrm{~A}$. Exocytosis did not increase linearly with pulse duration and showed satura- 


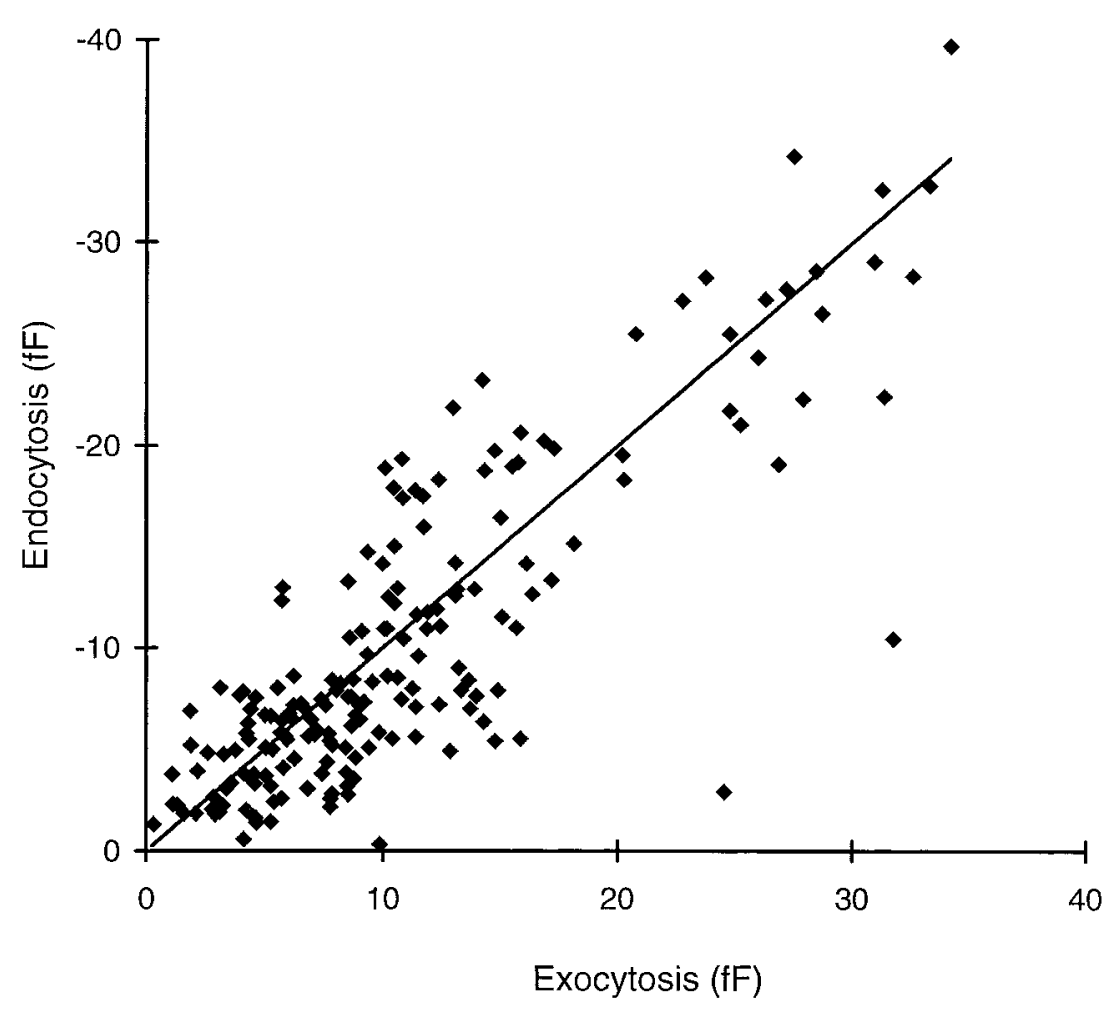

Figure 9. Fast exocytosis and rapid endocytosis are strongly coupled. The amplitude of exocytosis and rapid endocytosis at the same pulse show a high correlation (Spearman's $\rho=0.80 ; p<0.01$ ). Amplitude of exocytosis and endocytosis was determined as illustrated in Figure $6 A$. These values were corrected for changes in $\Delta C_{\mathrm{m}}$ not related to exocytosis and endocytosis. The solid line represents $y=x$. tion at the longer pulse durations. However, when the cumulative number of calcium ions that came into the cell during the 15 pulses is plotted against pulse duration (Fig. 11B), this also showed saturation at the longer pulse durations caused by increased inactivation at longer pulse durations (Fig. 10). As a result, the efficacy, the amount of capacitance change as a fraction of the number of calcium ions, is constant for all pulse durations up to $40 \mathrm{msec}$ (Fig. 11C). Per one million calcium ions approximately $1 \mathrm{fF}$, that is one vesicle, is released. This indicates that in melanotropes release of readily releasable vesicles is directly proportional to the number of calcium ions that enters the cell. So, secretion in melanotropic cells is regulated quite precisely by the time that calcium channels are open and calcium is entering the cell.

\section{DISCUSSION}

\section{Short step depolarizations evoke fast exocytosis}

Exocytosis occurs in multiple phases, not only in neuroendocrine cells such as melanotropes (Thomas et al., 1990; Thomas et al., 1993a,b; Parsons et al., 1995), chromaffin cells (Neher and Zucker, 1993; Heinemann et al., 1994; Horrigan and Bookman, 1994; Seward and Nowycky, 1996), and PC12 cells (Kasai et al., 1996), but also in peptidergic nerve terminals of the posterior pituitary (Seward et al., 1995) as well as central synapses (Goda and Stevens, 1994; Mennerick and Matthews, 1996). Fast exocytosis, defined as exocytosis occurring within $40 \mathrm{msec}$ at $30-34^{\circ} \mathrm{C}$ after a uniform rise in $\left[\mathrm{Ca}^{2+}\right]_{i}$ in melanotropes, is thought to result from the release of vesicles that are predocked on the cell membrane (Thomas et al., 1993a; Horrigan and Bookman, 1994; Parsons et al., 1995; Mennerick and Matthews, 1996). The slower phases of exocytosis are probably also the result of fusion of predocked vesicles, but these vesicles have to undergo one or more priming steps before they can actually be released (von Rüden and Neher, 1993; Thomas et al., 1993a,b; Parsons et al.,
1995). The immediately releasable pool of vesicles (available for fast exocytosis) is $\sim 250 \mathrm{fF}$ in melanotropic cells, whereas the total docked vesicle pool is $\sim 3300 \mathrm{fF}$ (Parsons et al., 1995). We found that during a $40 \mathrm{msec}$ step depolarization with $50 \mu \mathrm{M}$ intracellular EGTA only $\sim 3 \%$ of the immediately releasable pool is released. Thus, although immediate calcium concentration increases evoked by flash photolysis of caged calcium cause the release of a rapid pool of vesicles of $\sim 250 \mathrm{fF}$ within $40 \mathrm{msec}$ (Thomas et al., 1993a), these vesicles may have actually only a $3 \%$ chance to be released on the entry of $\sim 10^{7}$ calcium ions through voltage-gated calcium channels during a $40 \mathrm{msec}$ step depolarization.

The methods we used to calculate the amount of exocytosis and endocytosis neglected the fact that endocytosis might already have started during the depolarization and that exocytosis might have continued after the depolarization had ended. Therefore, all the values we obtained for exocytosis and endocytosis might be underestimations of the actual values. An independent measure of exocytosis, avoiding contamination by endocytosis, is to be found in the amperometric detection of the melanotropic cell hormone $\alpha \mathrm{MSH}$, as has been shown by Paras and Kennedy (1995). A definite quantification awaits such experiments.

\section{Predocked release-ready vesicles and voltage-gated calcium channels are far apart}

The present experiments examined the question of whether calcium channels are closely apposed to predocked release-ready vesicles in melanotropic cells. In a nano- or microdomain (Schweizer et al., 1995) around the channel mouth, the calcium concentration rises to tens or hundreds of micromoles within 1 msec (Simon and Llinás, 1985; Roberts, 1994). Release of a vesicle present in this domain cannot be impaired by a slow calcium buffer such as EGTA, not even in high millimolar concentrations (Adler et al., 1991; Nowycky and Pinter, 1993; Roberts, 1994; von Gersdorff and Matthews, 1994; Mennerick and 


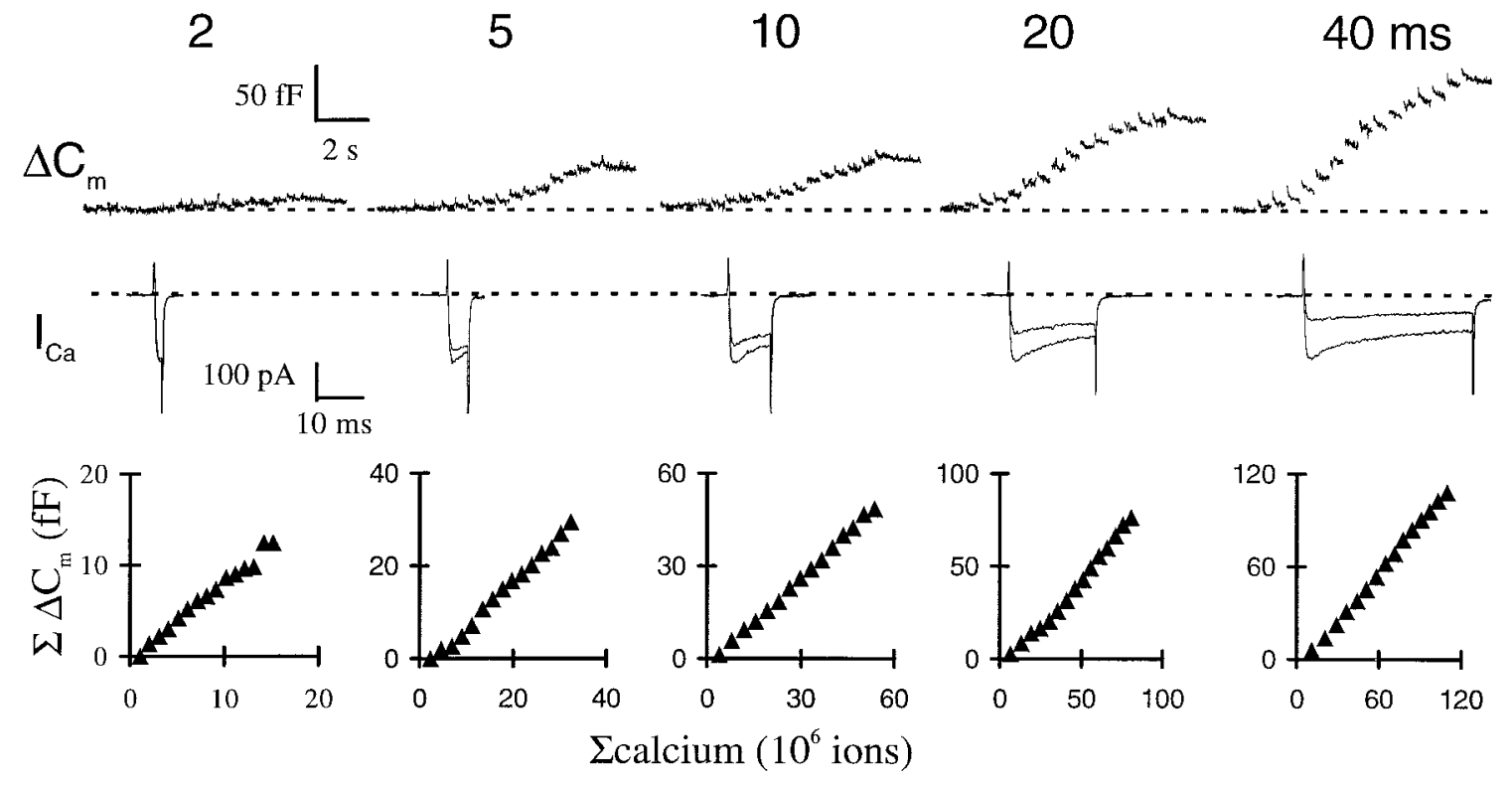

Figure 10. Exocytosis increases linearly with the amount of calcium influx at different pulse durations. The top traces $\left(\Delta C_{\mathrm{m}}\right)$ show an example of an increasing amount of $\Delta C_{\mathrm{m}}$ at trains of 15 pulses, with increasing pulse duration on the same cell. Pulse durations are indicated above the traces. The amount of exocytosis and endocytosis per pulse at the $40 \mathrm{msec}$ pulse duration are somewhat smaller than for the cells in Figure 6 . This might be attributable to the fact that the cells used for the experiments in Figure 6 were subjected to only one pulse train, whereas the cells for these experiments were all stimulated with 5 pulse trains with different pulse durations. Middle traces $\left(I_{\mathrm{Ca}}\right)$ show the current traces at the 1st and 15th step depolarization at the different pulse durations. Bottom plots show the cumulative capacitance change versus the cumulative number of calcium ions that entered the cell during the step depolarizations at different pulse durations. Each data point represents the average of eight different cells. Note that the values at axes change for each plot, but that the ordinate and abscissa values change proportionally, to show that the slope is roughly constant for all pulse durations. [EGTA $]_{\mathrm{i}}=50 \mu \mathrm{M}$.
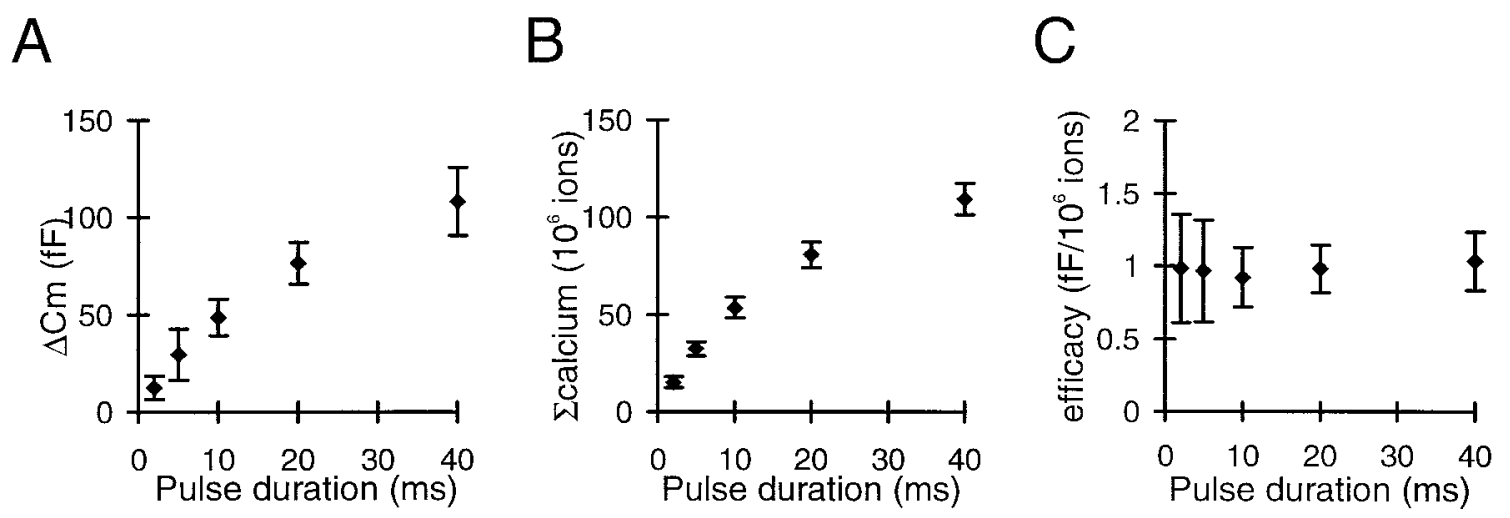

Figure 11. The efficacy of calcium ions to stimulate exocytosis is constant for different pulse durations. $A$, The cumulative capacitance change increases with increasing pulse duration. $B$, The cumulative number of calcium ions that entered the cell during the pulse train increases similarly with increasing pulse duration. $C$, The efficacy of calcium ions to stimulate exocytosis is constant for all pulse durations. Data were taken from the same cells as in Figure 10.

Matthews, 1996). In contrast, in our experiments EGTA already slightly affected fast exocytosis at $100 \mu \mathrm{M}$ and largely impaired exocytosis at concentrations of $400 \mu \mathrm{M}$. This shows that calcium channels and the predocked release-ready vesicles in melanotropes are not close together and calcium ions will have to diff use a large distance (i.e., $>100 \mathrm{~nm}$ ) to the release site. Probably, the influx of calcium through multiple calcium channels will contribute to the calcium concentration buildup near one predocked vesicle.

BAPTA, which has a $\sim 100$ times faster $k_{\text {on }}$ for calcium than EGTA, was only twice as effective in blocking fast exocytosis. This is an unexpected result if the calcium buffers are thought to be only in kinetic competition for calcium with the calcium sensor of the vesicle. Smaller differences in the effectiveness of BAPTA and EGTA in depressing exocytosis than predicted from calcium binding kinetics were also found for threshold secretion in peptidergic nerve terminals (Seward et al., 1995) and chromaffin cells (Seward and Nowycky, 1996). Both chelators were equally effective in shifting the calcium threshold for exocytosis, suggesting that the concentration of the chelator rather than the binding kinetics determines the threshold (Seward et al., 1995; Seward and Nowycky, 1996). However, in chromaffin cells, rapid release of predocked release-ready vesicles was not affected by $300 \mu \mathrm{M}$ BAPTA (Seward and Nowycky, 1996; Klingauf and Neher, 1997). This contrasts with the chelator sensitivity of secretion of the predocked release-ready vesicles we found in melanotropic cells, where at $200 \mu \mathrm{M}$ BAPTA fast exocytosis was depressed. Similar results were found in a neuronal preparation. In the synapse of Held, neurotransmission is depressed by $1 \mathrm{~mm}$ EGTA, whereas BAPTA was only 4-10 times more effective (Borst et al., 1995; 
Borst and Sakmann, 1996). The latter authors took this as support for their finding that opening of multiple calcium channels is necessary for transmitter release in this synapse (Neher, 1996).

\section{Exocytosis is tightly regulated}

If calcium channels and predocked release-ready vesicles are not closely adjacent, can fast exocytosis still be effectively regulated by the melanotropic cell? In melanotropes and chromaffin cells the rate of exocytosis has a third- to fourth-power dependence on the global intracellular calcium concentration (Thomas et al., 1990, 1993b; Heinemann et al., 1993). It was suggested therefore that the last steps in exocytosis of large dense-cored vesicles require the binding of three or more calcium ions. In addition, when calcium enters through calcium channels the resulting concentration profiles are nonuniform and highly dynamic. Despite these complexities in the relationship between calcium influx, calcium concentration, and the last steps in exocytosis, our results show that the amount of exocytosis was linearly proportional to the number of calcium ions that entered the cell during a pulse (Figs. 10, 11). So, although calcium channels and release-ready vesicles are not closely apposed to each other, the amount of exocytosis is tightly linked to the amount and duration of calcium entry.

A similar strong dependence of the probability of release on the flux of calcium and the duration of the flux was found in chromaffin cells (Engisch and Nowycky, 1996). In these cells too there is a considerable distance between calcium channels and predocked vesicles (Chow et al., 1992, 1994, 1996; Klingauf and Neher, 1997). Still, different types of calcium channels couple with different efficacies to exocytosis in these cells (Artalejo et al., 1994). Our results combine with these data to demonstrate that exocytosis of predocked large dense-cored vesicles in neuroendocrine cells is subject to regulation by timed and selective activity of voltage-gated calcium channels.

\section{Retrieval of exocytotic vesicles is rapid and calcium dependent}

Thomas et al. (1994) proposed a close coupling between exocytosis and endocytosis in melanotropes. After fusion, the vesicle does not flatten out into the plasma membrane but is retrieved again within a few seconds. At room temperature, retrieval of the exocytotic vesicle had two time constants, one of $3.5 \mathrm{sec}$ and one of $350 \mathrm{msec}$. In our experiments at $33^{\circ} \mathrm{C}$, retrieval had a time constant of $\sim 116 \mathrm{msec}$, and this was constant during the pulse train. An even faster time constant of membrane retrieval of $\sim 60$ msec was reported for chromaffin cells (Heinemann et al., 1994; for review, see Henkel and Almers, 1996). In addition, we found that the amplitude of endocytosis increased during a pulse train. After a few pulses the amplitude of endocytosis matched the amplitude of exocytosis at the same pulse quite well, giving rise to a strong correlation between exocytosis and endocytosis. This suggests that exocytotic vesicles are retrieved again with a time constant of $\sim 116 \mathrm{msec}$ immediately after the fusion step. A strong correlation between exocytosis and endocytosis was also found in PC12 cells (Kasai et al., 1996).

In chromaffin cells, rapid endocytosis is calcium dependent, and calmodulin is the receptor of calcium for this process (Artalejo et al., 1995, 1996). The fact that endocytosis was more sensitive to the calcium buffering capacity of the intracellular medium than exocytosis in our experiments shows that endocytosis is calcium dependent in melanotropic cells as well. The increase of the efficacy of calcium ions to stimulate rapid endo- cytosis during the pulse train might suggest that a slow calciumdependent factor is involved in rapid endocytosis that gets increasingly activated during the pulse train. When this factor is activated, endocytosis proceeds with a time constant of $\sim 116$ msec. This factor did not wash out of the cells during the first 5 min of the whole-cell recording, as was the case for slow endocytosis in saccular hair cells (Parsons et al., 1994). It remains to be established whether calmodulin is involved in melanotropic cells. Alternatively, an increased efficacy could result from a buildup of calcium underneath the membrane caused by summation between pulses. However, simulations of calcium concentration dynamics with parameters found in the present experiments showed that with a $500 \mathrm{msec}$ interpulse interval, the calcium concentration directly below the membrane drops rapidly to $100 \mathrm{~nm}$ after the pulse ends (T. A. de Vlieger and H. D. Mansvelder, unpublished results). An alternative interpretation of the observed increase in endocytosis during a pulse series, however, might be that slow exocytosis (occurring after each pulse) does play a role but diminishes during the pulse train. To resolve this issue, additional experiments with simultaneous amperometric detection of $\alpha \mathrm{MSH}$ are needed.

Thomas et al. (1994) showed by making perforated-patch recordings that rapid endocytosis does occur when the intracellular buffer system is kept intact. In our experiments, rapid endocytosis occurred only at very low concentrations of the slow calcium buffer EGTA. Thus, rapid endocytosis as well as exocytosis turn out to be very sensitive to mobile calcium chelators when trains of short step depolarizations are used. This suggests that the endogenous mobile buffer capacity of melanotropic cells must be relatively weak, compared with other systems (e.g., Roberts, 1993), in allowing processes such as exocytosis and rapid endocytosis to occur.

\section{REFERENCES}

Adler EM, Augustine GJ, Duffy SN, Charlton MP (1991) Alien intracellular calcium chelators attenuate neurotransmitter release at the squid giant synapse. J Neurosci 11:1496-1507.

Artalejo CR, Adams ME, Fox AP (1994) Three types of $\mathrm{Ca}^{2+}$ channel trigger secretion with different efficacies in chromaffin cells. Nature 367:72-76.

Artalejo CR, Henley JR, McNiven MA, Pafrey HC (1995) Rapid endocytosis coupled to exocytosis in adrenal chromaffin cells involves $\mathrm{Ca}^{2+}$, GTP, and dynamin but not clathrin. Proc Natl Acad Sci USA' 92:8328-8332.

Artalejo CR, Elhamdani A, Palfrey HC (1996) Calmodulin is the divalent cation receptor for rapid endocytosis, but not exocytosis, in adrenal chromaffin cells. Neuron 16:1-20.

Augustine GJ, Charlton MP, Smith SJ (1985) Calcium entry and transmitter release at voltage-clamped nerve terminals of the squid. J Physiol (Lond) 369:163-181.

Borst JGG, Sakmann B (1996) Calcium influx and transmitter release in a fast CNS synapse. Nature 383:431-434.

Borst JGG, Helmchen F, Sakmann B (1995) Pre- and postsynaptic whole-cell recordings in the medial nucleus of the trapezoid body of the rat. J Physiol (Lond) 489:825-840.

Calakos N, Scheller RH (1996) Synaptic vesicle biogenesis, docking, and fusion: a molecular description. Physiol Rev 76:1-29.

Chow RH, von Rüden L, Neher E (1992) Delay in vesicle fusion revealed by electrochemical monitoring of single secretory events in adrenal chromaffin cells. Nature 356:60-63.

Chow RH, Klingauf J, Neher E (1994) Time course of $\mathrm{Ca}^{2+}$ concentration triggering exocytosis in neuroendocrine cells. Proc Natl Acad Sci USA 91:12765-12769.

Chow RH, Klingauf J, Heinemann C, Zucker RS, Neher E (1996) Mechanisms determining the time course of secretion in neuroendocrine cells. Neuron 16:369-376.

Douglas WW, Taraskevich PS (1980) Calcium component to action potentials in rat pars intermedia cells. J Physiol (Lond) 309:623-630. 
Engisch EL, Nowycky MC (1996) Calcium dependence of large densecored vesicle exocytosis evoked by calcium influx in bovine adrenal chromaffin cells. J Neurosci 16:1359-1369.

Fidler N, Fernandez JM (1989) Phase tracking: an improved phase detection technique for cell membrane capacitance measurements. Biophys J 56:1153-1162.

Fidler Lim N, Nowycky MC, Bookman RJ (1990) Direct measurement of exocytosis and calcium currents in single vertebrate nerve terminals. Nature 344:449-451.

Goda Y, Stevens CF (1994) Two components of transmitter release at a central synapse. Proc Natl Acad Sci USA 91:12942-12946.

Heinemann C, von Rüden L, Chow RH, Neher E (1993) A two-step model of secretion control in neuroendocrine cells. Pflügers Arch 424:105-112.

Heinemann C, Chow RH, Neher E, Zucker RS (1994) Kinetics of the secretory response in bovine chromaffin cells following flash photolysis of caged $\mathrm{Ca}^{2+}$. Biophys J 67:2546-2557.

Henkel AW, Almers W (1996) Fast steps in exocytosis and endocytosis studied by capacitance measurements in endocrine cells. Curr Opin Neurobiol 6:350-357.

Horrigan FT, Bookman RJ (1994) Releasable pools and the kinetics of exocytosis in adrenal chromaffin cells. Neuron 13:1119-1129.

Joshi C, Fernandez JM (1988) Capacitance measurements. An analysis of the phase detector technique used to study exocytosis and endocytosis. Biophys J 53:885-892.

Kasai H, Takagi H, Ninomiya Y, Kishimoto T, Ito K, Yoshida A, Yoshioka T, Miyashita Y (1996) Two components of exocytosis and endocytosis in phaeochromocytoma cells studied using caged $\mathrm{Ca}^{2+}$ compounds. J Physiol (Lond) 494:53-65.

Keja JA, Stoof JC, Kits KS (1991) Voltage-activated currents through calcium channels in rat pituitary melanotropic cells. Neuroendocrinology 53:349-359.

Klingauf J, Neher E (1997) Modelling buffered $\mathrm{Ca}^{2+}$ diffusion near the membrane: implications for secretion in neuroendocrine cells. Biophys J 72:674-690.

Mansvelder HD, Kits KS (1997) Exocytosis and rapid endocytosis are differentially affected by the intracellular calcium buffering capacity in rat pituitary melanotropic cells. Biophys J 72:A118.

Mansvelder HD, Stoof JC, Kits KS (1996) Dihydropyridine block of $\omega$-agatoxin IVA and $\omega$-conotoxin GVIA sensitive $\mathrm{Ca}^{2+}$ channels in rat pituitary melanotropic cells. Eur J Pharmacol 311:293-304.

Mennerick S, Matthews G (1996) Ultrafast exocytosis elicited by calcium current in synaptic terminals of retinal bipolar neurons. Neuron 17:1241-1249.

Neher E (1996) Help from fast synapses. Nature 383:393-394.

Neher E, Marty A (1982) Discrete changes of cell membrane capacitance observed under conditions of enhanced secretion in bovine adrenal chromaffin. Proc Natl Acad Sci USA 79:6712-6716.

Neher E, Zucker RS (1993) Multiple calcium-dependent processes related to secretion in bovine chromaffin cells. Neuron 10:21-30.

Nowycky MC, Pinter MJ (1993) Time courses of calcium and calciumbound buffers following calcium influx in a model cell. Biophys J 64:77-91.
Paras CD, Kennedy RT (1995) Electrochemical detection of exocytosis at single rat melanotrophs. Anal Chem 67:3633-3637.

Parsons TD, Lenzi D, Almers W, Roberts WM (1994) Calciumtriggered exocytosis and endocytosis in an isolated presynaptic cell: capacitance measurements in saccular hair cells. Neuron 13:875-883.

Parsons TD, Coorssen JR, Horstmann H, Almers W (1995) Docked granules, the exocytotic burst, and the need for ATP hydrolysis in endocrine cells. Neuron 15:1085-1096.

Roberts WM (1993) Spatial calcium buffering in saccular hair cells. Nature 363:74-76.

Roberts WM (1994) Localization of calcium signals by a mobile calcium buffer in frog saccular hair cells. J Neurosci 14:3246-3262.

Schweizer FE, Betz H, Augustine GJ (1995) From vesicle docking to endocytosis: intermediate reactions of exocytosis. Neuron 14:689-696.

Seward EP, Nowycky MC (1996) Kinetics of stimulus-coupled secretion in dialyzed bovine chromaffin cells in response to trains of depolarizing pulses. J Neurosci 16:553-562.

Seward EP, Chernevskaya NI, Nowycky MC (1995) Exocytosis in peptidergic nerve terminals exhibits two calcium sensitive phases during pulsatile calcium entry. J Neurosci 15:3390-3399.

Simon SM, Llinás R (1985) Compartmentalization of the submembrane calcium activity during calcium influx and its significance in transmitter release. Biophys J 48:485-498.

Smith PD, Liesegang GW, Berger RL, Czerlinski G, Podolsky J (1984) A stopped-flow investigation of calcium ion binding by ethylene glycol bis $\left(\beta\right.$-aminoethyl ether)- $N, N^{\prime}$-tetraacetic acid. Anal Biochem 143:188-195.

Thomas P, Suprenant A, Almers W (1990) Cytosolic Ca ${ }^{2+}$, exocytosis, and endocytosis in single melanotrophs of the rat pituitary. Neuron 5:723-733.

Thomas P, Wong JG, Almers W (1993a) Millisecond studies of secretion in single rat pituitary cells stimulated by flash photolysis of caged $\mathrm{Ca}^{2+}$. EMBO J 12:303-306.

Thomas P, Wong JG, Lee AK, Almers W (1993b) A low affinity Ca ${ }^{2+}$ receptor controls the final steps in peptide secretion from pituitary melanotrophs. Neuron 11:93-104.

Thomas P, Lee AK, Wong JG, Almers W (1994) A triggered mechanism retrieves membrane in seconds after $\mathrm{Ca}^{2+}$-stimulated exocytosis in single pituitary cells. J Cell Biol 124:667-675.

Tsien RY (1980) New calcium indicators and buffers with high selectivity against magnesium and protons: design, synthesis, and properties of prototype structures. Biochemistry 19:2396-2404.

von Gersdorff H, Matthews G (1994) Dynamics of synaptic vesicle fusion and membrane retrieval in synaptic terminals. Nature 367:735-739.

von Rüden L, Neher E (1993) A Ca-dependent early step in the release of catecholamines from adrenal chromaffin cells. Science 262:1061-1065.

Williams PJ, MacVicar BA, Pittman QJ (1990) Electrophysiological properties of neuroendocrine cells of the intact rat pars intermedia: multiple calcium currents. J Neurosci 10:748-756.

Zhou Z, Misler S (1995) Action potential-induced quantal secretion of catecholamines from rat adrenal chromaffin cells. J Biol Chem 24: 3498-3505. 